\title{
The function of the central nervous system after haemorrhage
}

\author{
ARISZTID G. B. KOVÁCH \\ From the Experimental Research Department, Semmelweis University Medical School, Budapest, \\ Hungary
}

In the first description of the characteristic symptoms following severe physical trauma, Ambroise Paré in 1575 mentioned that the features of this condition are: flaccid, atonic musculature, cold sweat, feeble, quick pulse, unresponsiveness, and general indifference. Defects in nervous function are evident from this description. In 1889, Crile (Crile and Lower, 1899) suggested from experimental results that the central nervous system played an important role in the development of shock. He thought that impulses originating from the injured areas inhibited the medullary vasomotor centres, thus reducing blood pressure and, if lasting long enough, resulting in a definite impairment of the circulation. Opinions in the literature disagree on the role of somatic and visceral nociceptive afferent impulses in the development of irreversible shock (Slome and O'Shaughnessy, 1938; Overman and Wang, 1947; Arshawskaya, 1950; Guthrie, 1957; Popov, 1959). Later, other theories gained dominance and the interest in the nervous changes in shock gradually disappeared. But the regulatory adjustments needed to preserve physiological homeostasis depend on the nervous system so that when a progressive deterioration in homeostatic adjustment develops in response to haemorrhage nervous function must be affected.

This report is concerned principally with investigations carried out in our Institute in Budapest, where one of the chief subjects of investigation has been the functional and metabolic changes in the central nervous system and the significance of altered regulatory processes in the development of haemorrhagic shock.
Biochemical Changes in Brain Tissue after Trauma to the Body

In our earlier investigations on rats in traumat shock (Kovách, Bagdy, Balázs, Antoni, Gergel Menyhárt, Irányi, and Kovách, 1952) it w found that the adenosine triphosphate (ATP) and creatine phosphate $(\mathrm{CrP})$ concentratio decreased significantly only in the terminal stages. These findings were contrary to those of McSha Potter, Goldman, Shipley, and Meyer (1945) buit were confirmed by Stoner and Threlfall (1954). Like the last named authors, we have found that severe adynamia and impaired reflexes can observed in shock while the energy-rich $P$ contegt of the brain is still normal (Fonyó, Kovách, and Kovách, 1957; Kovách, Fonyó, and Kovácb̆, 1959a). However, normal concentrations $\bar{\delta} f$ ATP and CrP do not necessarily imply that the

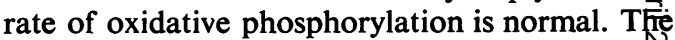
actual energy-rich $\mathbf{P}$ content depends on thre equilibrium between synthesis and utilizations. We could demonstrate that the rate of synthesis of energy-rich $\mathbf{P}$ in the brain was decreased despite normal concentrations. If the concęntration of CrP was reduced by bitemporal electrical stimulation, its rate of resynthesis on the injured rats was very much slower than normal rats (Kovách, Fonyó, and Kovác历, 1958 b). It was also found that the incorporatien of ${ }^{32} \mathbf{P}$ into the energy-rich $\mathbf{P}$ compounds waids significantly lower in shock than under normal conditions (Kovách and Fonyó, 1965).

The acetylcholine content of the brain wâs found to increase considerably after trauma (Kovách, Fonyó, and Halmágyi, 1958a). 
More recent investigations have shown that there is a significant increase in the potassium content of the brain after trauma (Kovách, Kellner, and Maklári, 1965a). This is of interest as we had previously found that an increase in the potassium concentration altered the $P$ metabolism of the brain in vitro (Fonyó, Kovách, Maklári, Leszkovszky, and Meszáros, 1958).

\section{Perfusion of the Isolated Head}

Studying the metabolism of the brain in vivo in tourniquet and haemorrhagic shock, Kovách, Roheim, Irányi, Kiss, and Antal (1958d) observed the effect of perfusion of the isolated head. The circulation to the head of the dog was isolated from the trunk and the head was perfused with

Parameters measured simultaneously in standardized hemorr-

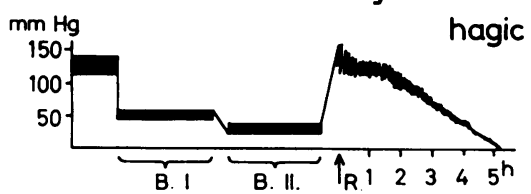

Systolic and diastolic art. pressure
Right atrial pressure
Heart frequency
ECG II.
Cardiac output
C. o. head and forelimbs-flow
C. o. splanchnic-flow
C. o. pelvic and rearlimbs-flow
Ventillation
Electrocorticogram
Hemoglobin
Hematokrit
Rectal temperature

ALVAR VISIOGRAPH SUPRA "8" BECKMAN micro-hematokrit centrifuge

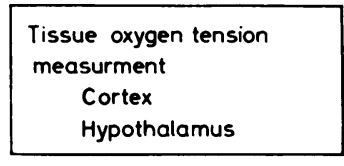

POLAROGRAPHIC PRINCIPLE KUTESZ 4-channel instrument BECKMAN physiological gas analyzer Mod. 160

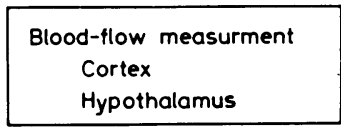

HENSEL PRINCIPLE by heated thermo couple HARTMANN AND BRAUN FLUVOGRAPH

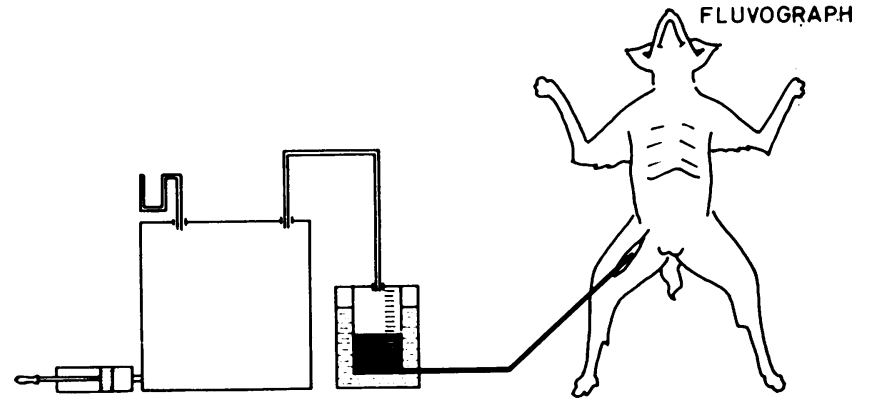

Bleeding by the LAMSON technique (ENGELKING - WILLIG)

Fig. 1 Summary of the experimental protocol in haemorrhagic shock experiments on dogs illustrating the two periods of haemorrhagic hypotension referred to in the text as BI and BII and the typical changes in blood pressure after reinfusion at $\mathrm{R}$. blood from donor dogs. Only the spinal cord and the vagosympathetic trunk remained intact between the head and the body of the acceptor dog (Kovách, 1954). The purpose was to determine whether a normal supply of blood to the head would modify the course of shock. Tourniquet shock was induced by ligating both hind limbs at the inguinal level for five hours. Haemorrhagic shock was induced by a modified Wiggers method, ie, maintaining the blood pressure at $55 \mathrm{~mm} \mathrm{Hg}$ for 60 minutes, then at $35 \mathrm{~mm} \mathrm{Hg}$ for another 60 minutes (Wiggers, 1950).

Perfusion of the isolated head lengthened the survival time in both tourniquet and haemorrhagic shock. The survival time was, in both cases, significantly longer. Intracarotid perfusion, without isolation of the head, with $50 \mathrm{ml}$ blood/ min during the hypovolaemic period also lengthened the survival time of animals in haemorrhagic shock, and, in $50 \%$ of cases resulted in a complete survival despite the fact that an equal quantity of blood was continuously withdrawn from the jugular vein and femoral artery (Kovách et al, 1958d). Perfusion of the isolated head during the hypotensive period of haemorrhagic shock also completely restored renal function compared with the control shock animals which had anuria (Kovách, Roheim, Irányi, and Kovách, 1958e).

\section{Electrocorticogram (ECoG)}

Because of all the tissues in the mammalian body the nervous tissue is the least capable of withstanding lack of oxygen, and because it is known that hypoxia changes the electrical activity of the central nervous system (van Liere and Stickney, 1963), we also studied the effect of haemorrhagic and ischaemic shock on the spontaneous cerebrocortical electrical activity (ECoG).

In the following experiments for inducing haemorrhagic shock a modified Lamson technique (Engelking and Willig, 1958) was used (Fig. 1). As a standard procedure, the dog, under chloralose anaesthesia, was kept on stabilized mean arterial blood pressure levels of 55 and 35 $\mathrm{mm} \mathrm{Hg}$ respectively (BI and BII). Each period was maintained for 90 minutes. After the oligaemic period all the blood remaining in the bottle was reinfused. Blood coagulation was prevented with heparin $(5 \mathrm{mg} / \mathrm{kg})$. The arterial and right atrial pressures, the ECG in standard lead II, respiration, and the ECoG on four leads was recorded on an eight-channel Alvar Visograph Supra. The cardiac output and the headforelimb, the splanchnic, and the pelvic-hind limb blood flow were measured by the thermodilution method as modified in our laboratory (Fronék and Ganz, 1960; Kovách and Mitsányi, 1964). Physiological saline at room temperature was injected into the aorta at three different 
points: in the ascending aorta, at the level of the diaphragm, and below the renal arteries. The thermistor was inserted to the bifurcation of the aorta through a branch of the femoral artery. The dilution curves were calculated with the aid of a Fischer cardiac output computer (Fischer A.G., Göttingen). The respiratory rate was measured with a thermistor in the tracheal cannula. The haemoglobin content and haematocrit value (microhaematocrit) of arterial blood, and in some cases of venous blood, was measured every 15 minutes.

In both haemorrhagic and tourniquet shock, significant changes were found in the ECoG (Kovách and Fonyó, 1960). Activity was impaired at 55 $\mathrm{mm} \mathrm{Hg}$ blood pressure and after a period of $\mathbf{3 0}$ min at $35 \mathrm{~mm} \mathrm{Hg}$ activity ceased and only isoelectric readings were recorded. When the animals were reinfused the ECoG activity did not return although the blood pressure remained within the normal range for a considerable time. In some cases further blood transfusion was given without improvement in the ECoG. In dogs so bled that the BII period was not longer than 35 minutes (Fig. 1) the ECoG returned almost completely to normal $30-90 \mathrm{~min}$ after reinfusion.

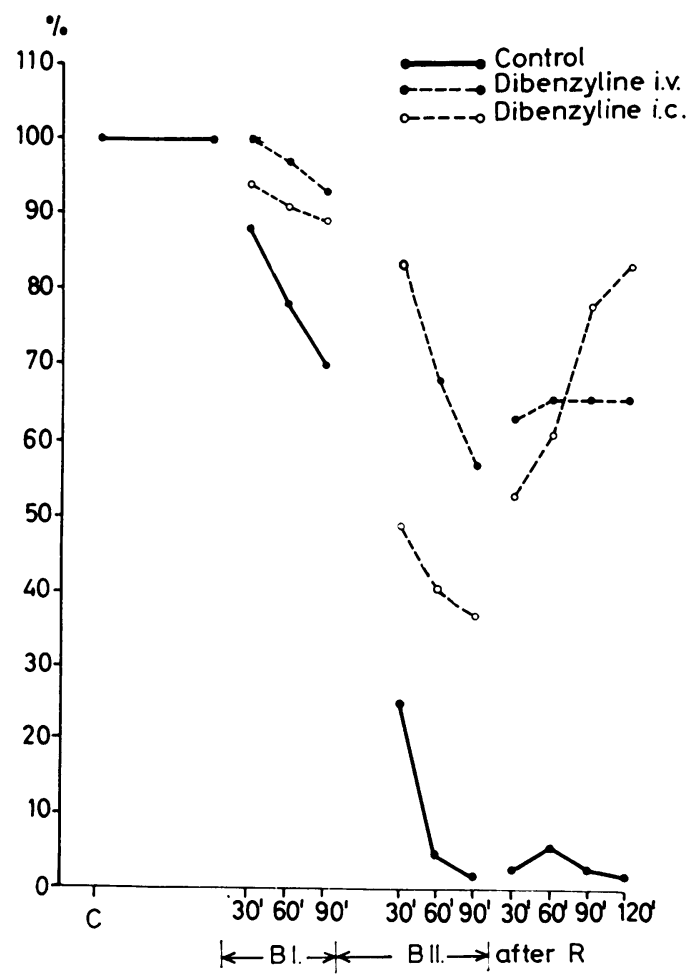

Fig. 2 The changes in the electrocorticogram during and after haemorrhagic hypotension in untreated control dogs and dogs pretreated with phenoxybenzamine (Dibenzyline), either $5 \mathrm{mg} / \mathrm{kg}$ i.v. or $0.5 \mathrm{mg} / \mathrm{kg}$ i.c. Average starting wave amplitude expressed as $100 \%$.
Phenoxybenzamine, $5 \mathrm{mg} / \mathrm{kg}$ intravenously $\frac{\mathcal{O}}{\bar{P}}$ $0.5 \mathrm{mg} / \mathrm{kg}$ intracarotid before bleeding, protected against the impairment of activity. The ECof changes in different phases of shock after haemo?. rhage are summarized in Figure 2. The average wave amplitude analyses are expressed as percentages, the starting wave amplitudes being taken as $100 \%$. The same pretreatment wi phenoxybenzamine lengthened the survival tinge and increased the survival rate of dogs in haemos rhagic shock (Menyhárt, Kovách, Kiss, Erdélỹ̆, and Kovách, 1954; Kovách et al, 1958d). The recovery of the hypoxic ECoG changes depended largely on the available oxygen, the blood flow through the brain, and the duration of hypoxit. The loss of ECoG activity could be explained Ey the fact that during oligaemia the brain lactic aced increases and the extracellular potassium concentration rises to levels at which brain metabolism is depressed (Kovách and Fonyó, 1960). N

\section{Spontaneous Activity in the Hypothalamus}

Subsequently we investigated the spontaneots bioelectrical activity in the hypothalamus and $\overrightarrow{\dot{m}}$ the reticular formation in dogs anaesthetized with chloralose (Kovách, Fedina, Mitsánxi, Naszlady, and Biró, 1962). The spontaneous electrical activity in these regions disappeared after bleeding at the same time and in the sarge way as the ECoG.

\section{Cerebral Blood Flow}

It has been shown that when the cortical bloed flow increases, the mean frequencies in electricortical activity also increase and vice versa (Lee, Tindall, Greenfield, and Odom, 1966; Baldy-Moulinier and Ingvar, 1968). The question arises whether a decrease in cerebral blood flof followed by cerebral hypoxia could impair the cerebral bioelectrical activity. Jourdan, Collę, and Masbarnard (1950) studied the changes in the calibre of the cerebrocortical vessels through a window but did not find alterations after haemorrhage. Kovách, Roheim, Irányi, Cserháẩ, Gosztonyi, and Kovách (1959b) found that Th ischaemic limb shock the mean blood flow through the head measured with a rotametor decreased $20-25 \%$ but this change alone could not be responsible for the severe cerebral hypoxła and neural impairment because this degree of restriction in the blood flow did not affect the ECoG when tested in separate experiments.

Total cerebral blood flow measurements cagnot give information about changes in regional flow so that in our next experiments cerebrocortical and hypothalamic blood flow ws measured. Two methods were used on dogs 
chloralose anaesthesia. One method was that described by Hensel and Ruef (1959) based on the measurement of the thermal conductivity of the tissues. Continuous recording was carried out with a direct writing two-channel device (Fluvograph, Hartmann and Braun, Frankfurt). The probes were made according to Betz et al (1961) and were inserted into the cortex or

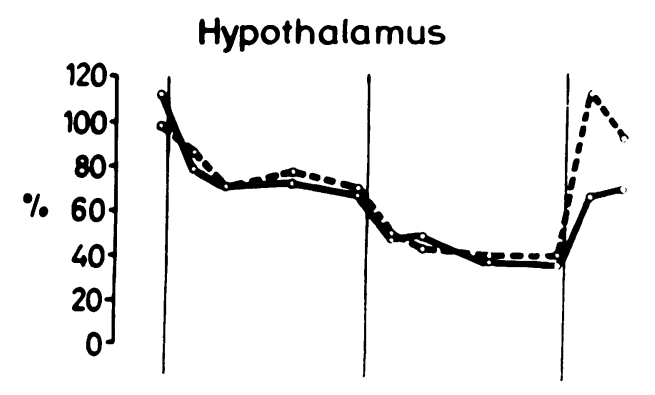

Liver

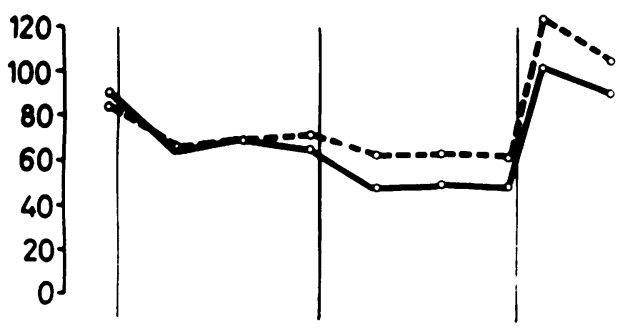

Muscle

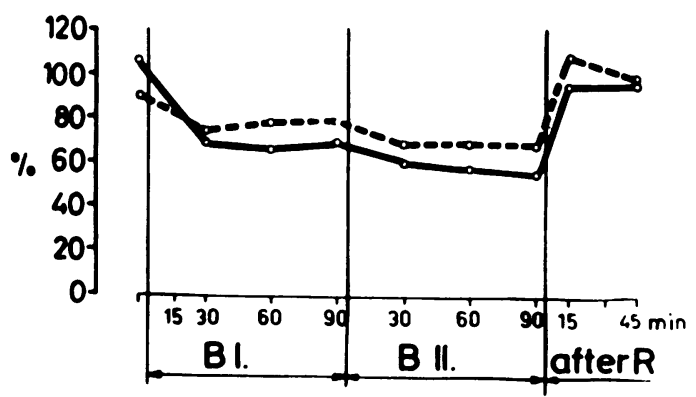

Fig. 3 Blood flow through various organs and tissues during and after haemorrhagic hypotension in dogs measured by the $\mathrm{H}_{2}$ electrode method except in the case of adipose tissue where flow was measured by the method of Rosell (1966). The initial flow measured by the $\mathrm{H}_{2}$ electrode is expressed as $100 \%$. The interrupted lines show the changes in dogs pretreated with phenoxybenzamine (Dibenzline) $5 \mathrm{mg} / \mathrm{kg}$ i.v. hypothalamus with a stereotactic apparatus.

Blood flow records were evaluated in terms of relative (percentage) thermal conductivity. The difference between the thermal conductivity $(\Delta \lambda)$ at the beginning of the experiment and after death is referred to as $100 \%$ (Kovách, Mitsányi, and Stekiel, 1965b).

The $\mathrm{H}_{2}$ washout method described by Aukland,

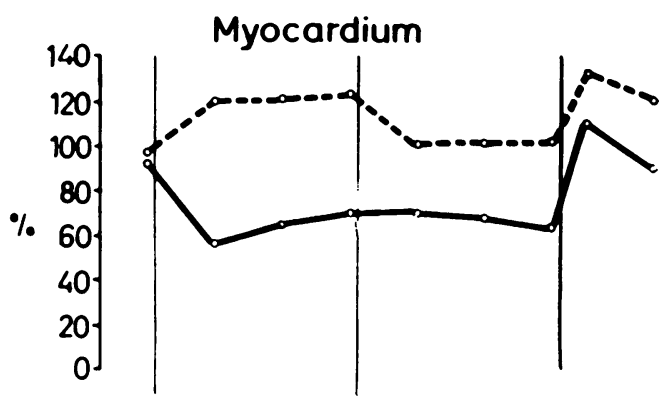

Kidney
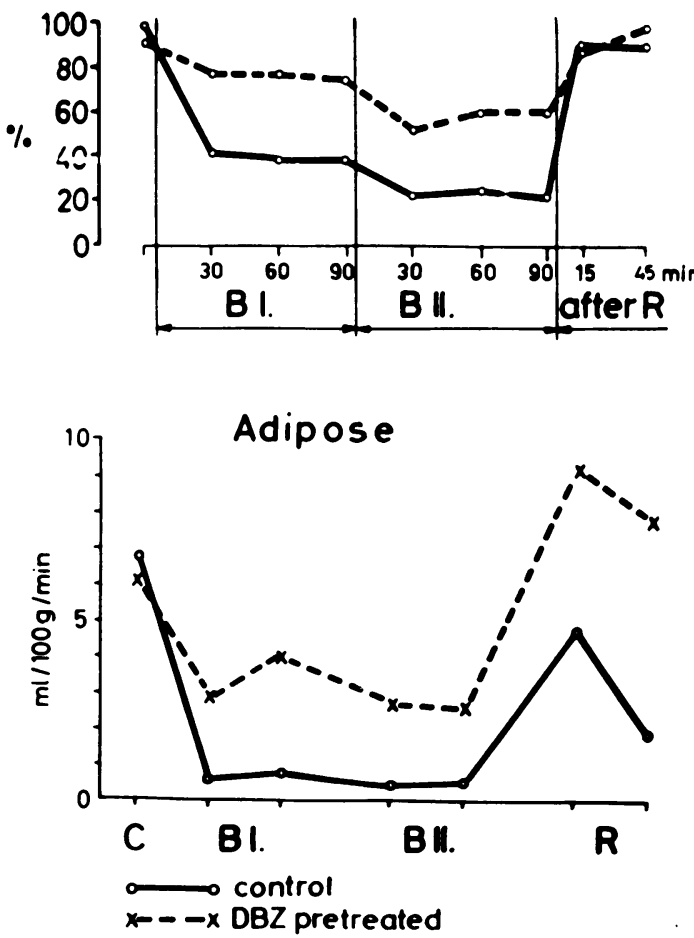
Bower, and Berliner (1964) was also adapted for the measurement of local blood flow. Two or three platinum electrodes, $0.5 \mathrm{~mm}$ in diameter, were introduced by a stereotactic apparatus into the cerebral cortex and hypothalamus (nucleus ventromedialis). The electrodes were insulated with Insl-X (Insl-X Products Corp. Yonkers, N.Y.) leaving $0.8 \mathrm{~mm}$ bare at the tip. The indifferent electrode of the circuit was a calomel electrode introduced under the skin of the leg via a polyethylene tubing $\mathrm{KCl}$-agar bridge. A positive polarizing potential of $250 \mathrm{mV}$ was supplied to the measuring electrodes. Hydrogen saturation of the tissues was attained by inhaling the gas. The exponential desaturation curves were recorded on a Kipp BD-3 micrograph and transferred to semi-logarithmic paper; the slope of the line thus obtained is proportional to blood flow which can be calculated in $\mathrm{ml} / \mathrm{min} / \mathrm{g}$ according to the method of Kety (1960).

In the bleeding period I the cerebral cortical blood flow remained unchanged when examined by both methods. In the BII period it fell to 70 to $80 \%$ of the original flow level. The blood flow changes were different in the hypothalamic region where the flow fell to $65 \%$ in the $\mathrm{BI}$ period and to $40 \%$ of the original value in the BII period (Fig. 3). In Fig. 3 we can compare these blood flow changes with those in other tissues. It is clear that the hypothalamus is not so well protected against a fall in blood pressure after haemorrhage as the cortex. It is interesting to note that there is no difference in cerebral and hypothalamic blood flow between the control and groups pretreated with phenoxybenzamine after haemorrhage (Kovách et al, 1965b). This finding is especially interesting, because as was shown

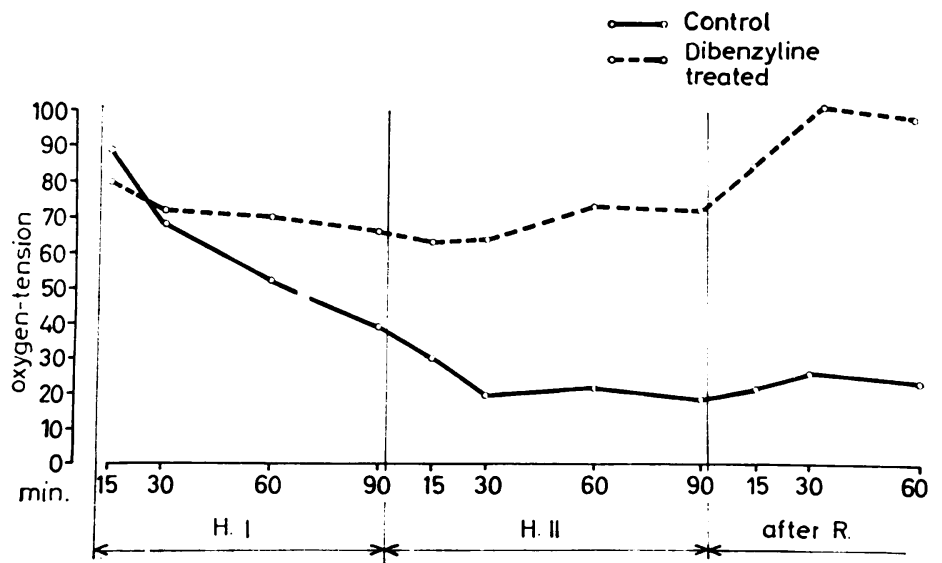

Fig. 4 The changes in $\mathrm{pO}_{2}$ in the hypothalamus during and after haemorrhagic hypotension in untreated control dogs and dogs pretreated with phenoxybenzamine (Dibenzyline) $5 \mathrm{mg} / \mathrm{kg}$ i.v. (interrupted line). The initial $\mathrm{pO}_{2}$ is expressed as $100 \%$. earlier, such pretreatment protects against the ECoG changes in shock. $\mathrm{H}_{2}$ desaturatiog measurements also showed a fall in blood flow like that described with the heat clearanee method. These results would suggest that tie hypothalamic blood flow autoregulation differs from that in other parts of the brain. The question arises whether or not we are dealia with a defensive or protective mechanism.

\section{Cerebral Oxygen Tension}

Because we could not find any difference in blogid flow changes between the controls and groups pretreated with phenoxybenzamine after haemon rhage, the question arose as to whether there wefe differences in regional oxygen utilization in the brain. The $\mathrm{O}_{2}$ tension in the hypothalamus w\& measured polarographically with platinum microelectrodes (Beckman). We found a continuous and progressive decrease in $\mathrm{pO}_{2}$ during the $\mathrm{BI}$ and BII periods to below $20 \%$ of the initial value (Fig. 4). After reinfusion, the hypothalamic p $\Phi_{2}$ did not rise and remained at this low level despite a significant elevation in local blood flow. These results suggest that oxygen utilization is ip. creased in the hypothalamus after bleeding (Kovách et al, 1965b). An elevated cerebral consumption after limb ischaemia was described in earlier papers (Kovách, Menyhárt, Erdélgig, Molnár, and Kovách, 1958c). In-vitro studies algo showed that $\mathrm{O}_{2}$ uptake by brain slices from rats in shock was significantly higher than by brain slices from normal rats (Kovách, Fonyó, Vittay, and Pogátsa, 1957).

In the group treated with phenoxybenzamipie the $\mathrm{pO}_{2}$ in the hypothalamus showed a smaligr fall during the hypotensive period and returned to normal after reinfusion (Fig. 4).

\section{Cerebral A-V Oxygen Difference}

Figure 5 shows the arteriovenous $\mathrm{O}_{2}$ differences 16 control and 11 dogs treated with phenoxybenzamine in haemorrhagic shock. The sagit:al vein was cannulated and blood samples weuce taken every 15-20 minutes. The arterioveno $\mathrm{O}_{2}$ difference rose very considerably after haemorrhage in the untreated dogs. The A-Vळ్ difference remained high after reinfusion. Pretreatment with phenoxybenzamine had a definite effect, for in these animals the $\mathrm{A}-\mathrm{VO}_{2}$ differenee did not change after haemorrhage.

From the present results we can conclude th the cerebral hypothalamic $\mathrm{O}_{2}$ utilization imcreases considerably during haemorrhage so that the reduction in blood flow can result in sevefe local hypoxia. The increased total cerebral $\hat{\theta}_{2}$ utilization is maintained after reinfusion whle 


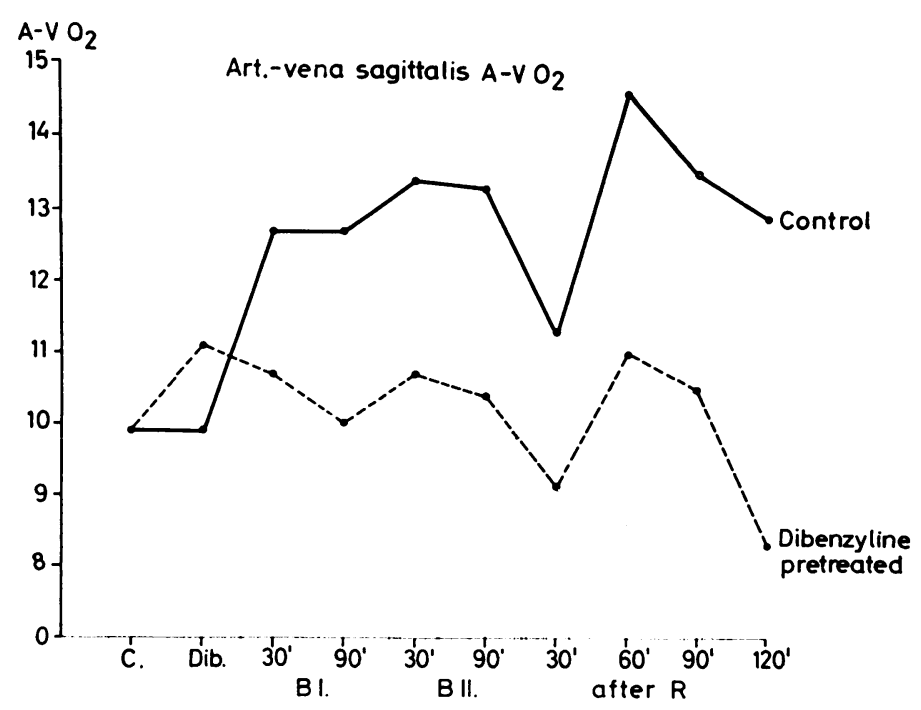

Fig. 5 The arteriovenous (sagittal vein) $\mathrm{O}_{2}$ differences during and after haemorrhagic hypotension in untreated control dogs and dogs pretreated with phenoxybenzamine (Dibenzyline) $5 \mathrm{mg} / \mathrm{kg}$ i.v. (interrupted line). $\mathrm{A}-\mathrm{V} \mathrm{O}_{2}$ differences expressed as percentages.

the blood flow is normal. Phenoxybenzamine prevented the increase in cerebral $\mathrm{O}_{2}$ consumption, and, consequently, the $\mathrm{pO}_{2}$ was less reduced during bleeding. After reinfusion, the hypothalamic $\mathrm{pO}_{2}$ became normal in animals treated with phenoxybenzamine. This suggests that the protective effect of pretreatment with phenoxybenzamine may be related to a local metabolic effect.

What are the causes of the increase in cerebral uptake in shock?

The increase in $\mathrm{O}_{2}$ uptake might be due to catecholamines inasmuch as King, Sokoloff, and Wechsler (1952) have shown that adrenaline increases $\mathrm{O}_{2}$ consumption in human cerebral tissue in vivo. This possibility is underlined by the fact that pretreatment with phenoxybenzamine reduced the elevated $\mathrm{O}_{2}$ consumption of the brain in shock in the present experiments. Other humoral factors may also play a part.

The significance of an increased flow of afferent nervous impulses has to be taken into consideration. Partial transection of the afferent pathways in the spinal cord (Swingle, Remington, Kleinberg, Drill, and Eversole, 1942), transection of the sinus or Hering nerve (Mylon and Winternitz, 1945), and vagal transection (Erdélyi and Kovách, 1961) all had a favourable effect on shock. On the basis of these results, it can be suggested that after haemorrhage or trauma both catecholamine secretion and nociceptor stimuli increase the metabolism of the central nervous system, which, together with the local tissue hypoxia, leads to functional impairment in the central regulatory functions. In this respect, the early impairment of hypothalamic function is especially important.

\section{Cerebral Hypercapnia}

It is known that characteristic changes in acidbase balance have been demonstrated in the course of haemorrhagic shock (Root, Allison, Cole, Holmes, Walcott, and Gregersen, 1947; Darby and Watts, 1964; Baubkus and Kirchheim, 1966).

Comparison of the $\mathrm{pH}$, bicarbonate, and $\mathrm{pCO}_{2}$ in carotid and sagittal venous blood suggests that the central nervous system must be involved in the disturbance of acid-base balance. It was striking to find that a significant increase in $\mathrm{pCO}_{2}$ in the blood of the sagittal vein develops during bleeding while the bicarbonate level declines in the same manner as in arterial blood. This causes a substantial fall in $p \mathrm{H}$, largely through the increase in $\mathrm{pCO}_{2}$. Acidity thus increases in the blood perfusing the brain. To examine the changes in the $\mathrm{CO}_{2}$ content of the brain tissue in haemorrhagic shock we performed experiments on dogs anaesthetized with chloralose. Both controls and animals treated with phenoxybenzamine were used. Blood samples were taken from the carotid artery and from the sagittal vein before bleeding, at the end of the BII period, one hour after reinfusion, and in the terminal phase of shock. After each blood sampling 10 animals were decapitated by a single blow. The skull was opened immediately, the brain was immersed in paraffin and specimens were excised from the frontal and occipital cortex, thalamus, hypothalamus, pons, and medulla oblongata. The samples were pulverized in liquid nitrogen and their $\mathrm{CO}_{2}$ content was estimated by the method of Anrep, Ayadi, and Talaat (1936).

The $\mathrm{CO}_{2}$ content in cerebral tissue obtained from six different parts of the brain ranged between 15 and $20 \mathrm{mmol}$ per $\mathrm{kg}$ wet weight before bleeding. At the end of the BII period, the figures had risen to $40 \mathrm{mmol}$ in the hypothalamus and to $30.5 \mathrm{mmol}$ in the frontal cortex, whereas the values found in the thalamus $(20.4$ mmol) and other regions were not significantly raised. Reinfusion was followed by a reduction of hypercapnia in the hypothalamus and the frontal cortex. With increasing severity of shock the $\mathrm{CO}_{2}$ content of cerebral tissue increased significantly again. The values as percentages of the prebleeding values are presented in Fig. 6 (Maklári and Kovách, 1966 and 1968).

Brain $\mathrm{CO}_{2}$ values in dogs pretreated with phenoxybenzamine before bleeding were higher than in the controls. Levels of over $20 \mathrm{mmol}$ per $\mathrm{kg}$ wet weight were found in the frontal cortex 
(23.1 mmol) and in the hypothalamus (26.3 mmol). Unlike the untreated animals the $\mathrm{CO}_{2}$ content of the cerebral tissue diminished but the reduction was not significant. No tissue hypercapnia was found after reinfusion either (Fig. 6).

From these results it may be inferred that haemorrhage affects the different parts of the central nervous system to different degrees. These results also suggest that the reduction in blood flow and the increase in $\mathrm{O}_{2}$ requirements during the hypotensive phase leads not only to hypoxia, but also to metabolic changes in the hypothalamus and frontal cerebral cortex as reflected by tissue hypercapnia and increasing acidosis. None of the dogs pretreated with phenoxybenzamine presented any of the signs of the severe acidosis found in the untreated dogs during haemorrhage. The $\mathrm{pCO}_{2}$ of the sagittal venous blood remained constant. This difference between the pretreated and the control animals is emphasized by the fact that as shown above the fall in blood flow during bleeding was the same in both groups. Infusion of buffer solutions has a similar effect (Fig. 7) to phenoxybenzamine, protecting the brain from hypercapnia in the BII period (Maklári, Kovách, and Nyáry, 1970).

We thought that phenoxybenzamine could exert a direct influence on tissue metabolism, reduci $\bar{x}$ the brain damage (Kovách, Menyhárt, Erdél她, Molnár, Kiss, Kovách, and Bodolay-Varg荈, 1961). To investigate the possible metabolic role of pretreatment with phenoxybenzamine, studied the effect of phenoxybenzamine on isolated rat liverand brain mitochondria (Kovácich, Koltay, and Kovách, 1970). It was found th phenoxybenzamine in concentrations of $2 \bar{\pi}^{5}$ $\mu \mathrm{g} / \mathrm{ml}$ medium and above reduced the metabofe activity of the rat liver mitochondria so thât state IV and state III respiration and te dinitrophenol-activated respiration were reduced (Fig. 8). A dose response effect is demonstrated in Figure 9. These results indicate thit phenoxybenzamine has metabolic actions $\frac{T}{\mathrm{~T}}$ addition to those of $a$-receptor blockade which might be concerned in the effect of pretreatment with phenoxybenzamine on the effects of haemorrhage.

\section{Hypothalamic Stimulation}

That the cardiovascular mechanisms controlled by the hypothalamus are greatly affected

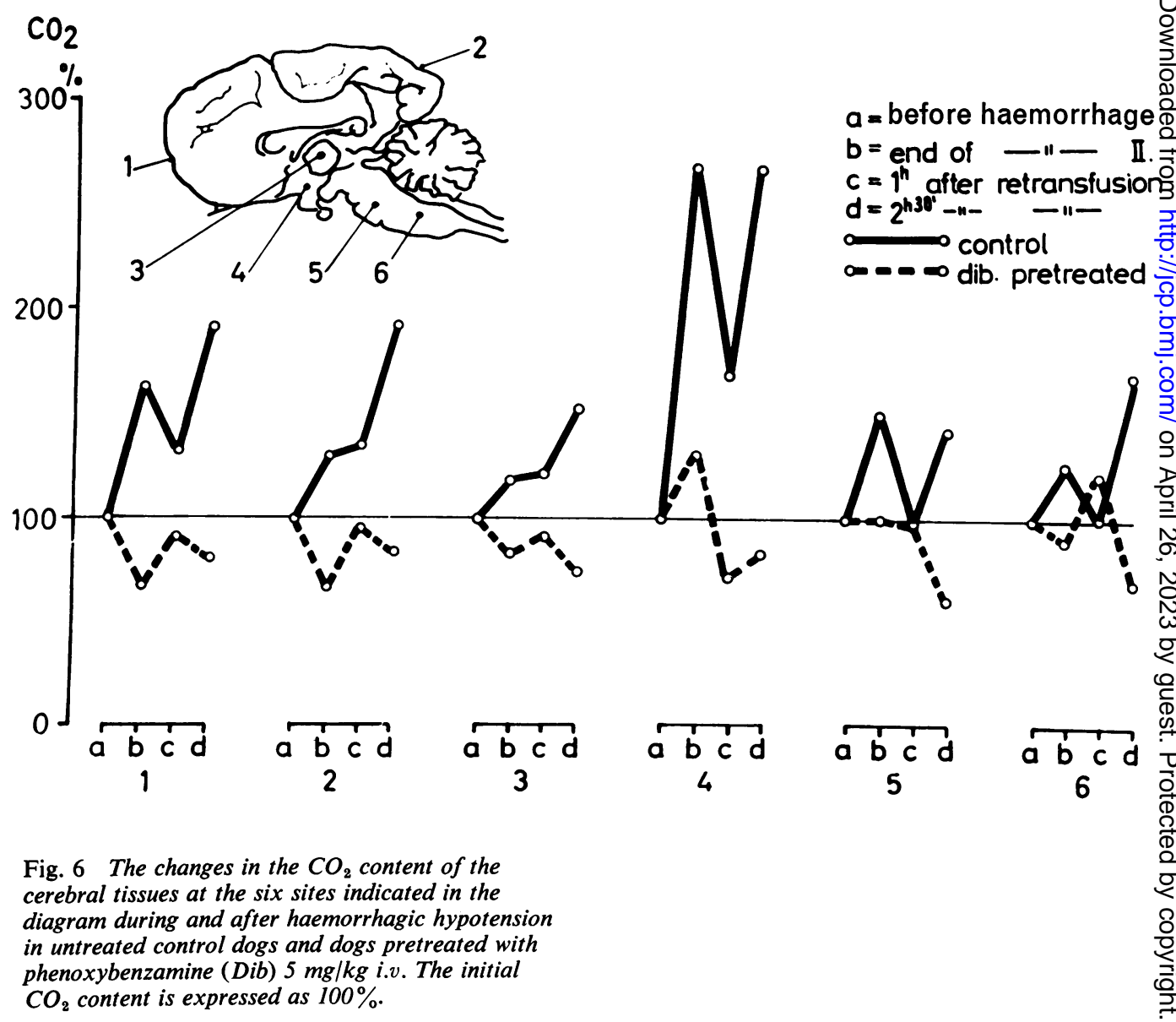




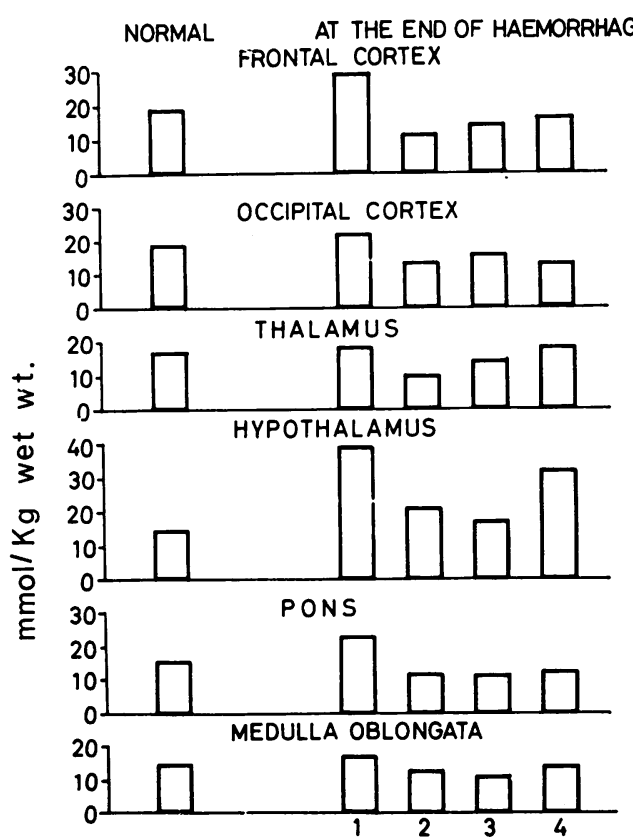

1:untreated 2: during B,continuousty adm. THAM buffer sol.

3: during B., continuously adm. bicarbonate solution

4: bicarbonate inf. in the last period of $B$.

Fig. 7 The changes in the $\mathrm{CO}_{2}$ content of six parts of the brain of dogs in haemorrhagic hypotension and being treated with different buffers.

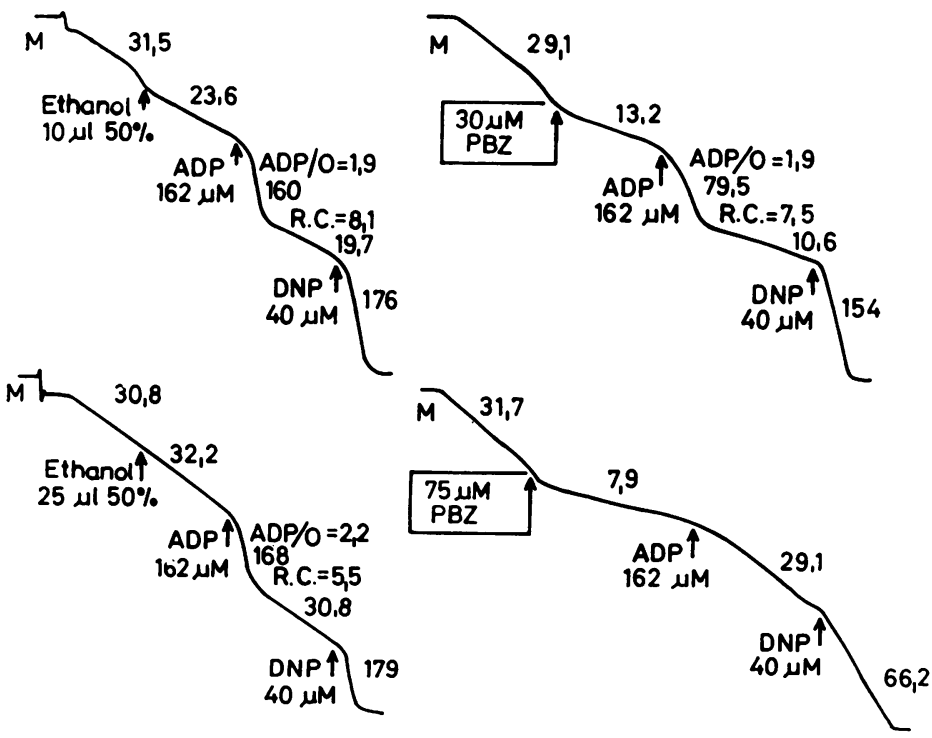

Fig. 8 The polarographic measurement of the respiration of four samples of rat liver mitochondria showing the inhibitory effect of phenoxybenzamine (PBZ) on state IV respiration and later, in the case of the higher dose, on the responses to the addition of adenosine diphosphate (ADP) and dinitrophenol (DNP). The phenoxybenzamine was dissolved in 50\% ethanol and the lack of effect of the addition of appropriate volumes of the solvent is shown by the tracings on the left. Tracings to be read from left to right. Mitochondria added at $\mathrm{M}$.

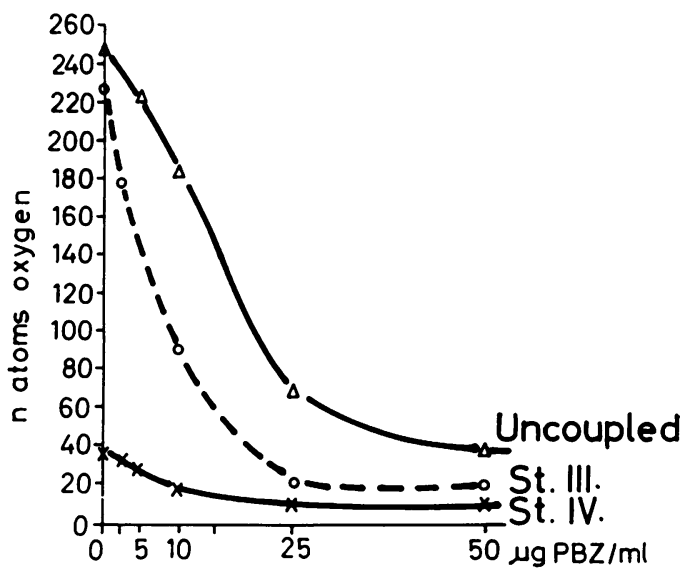

Fig. 9 Effect of phenoxybenzamine (PBZ) on the $\mathrm{O}_{2}$ uptake of rat liver mitochondria in different metabolic states.

haemorrhage is also shown by the following results. In 17 dogs in chloralose anaesthesia we studied the effect of stimulation of the hypothalamus and reticular formation during the course of haemorrhagic shock and after reinfusion. Stimulating electrodes were inserted either immediately or one week before the bleeding, using sterotactic apparatus. Before bleeding stimulation produced a marked cardiovascular effect (Fig. 10) which was abolished during bleeding and the stimulating voltage had to be increased to get a response in the BI period. The threshold level rose. In the BII period hypothalamic stimulation was without effect. In some cases reinfusion produced a short-lasting recovery but later the response to hypothalamic stimulation disappeared (Kovách et al, 1962). To be sure that peripheral disturbances were not responsible for these results we stimulated the medulla directly and obtained blood pressure responses (Fig. 11).

\section{Evoked Responses in the Hypothalamus}

Hypothalamic neural impairment could also be demonstrated by studying the evoked responses (Kovách, Dóra, and Nyáry, 1970). These experiments were carried out on dogs anaesthetized with chloralose. Electrodes were inserted with a stereotactic device into the fornix and the nucleus ventromedialis. The first electrode was used for stimulation, the second for recording the evoked response. In Fig. 12 we can see the control evoked response. After bleeding the animals to $55 \mathrm{~mm} \mathrm{Hg}$ for 30 minutes the evoked response changed, the positive wave disappearing. Reinfusion of the shed blood did not fully restore the response. Bleeding the dog again to $55 \mathrm{~mm}$ $\mathrm{Hg}$ and holding the blood pressure at this level 


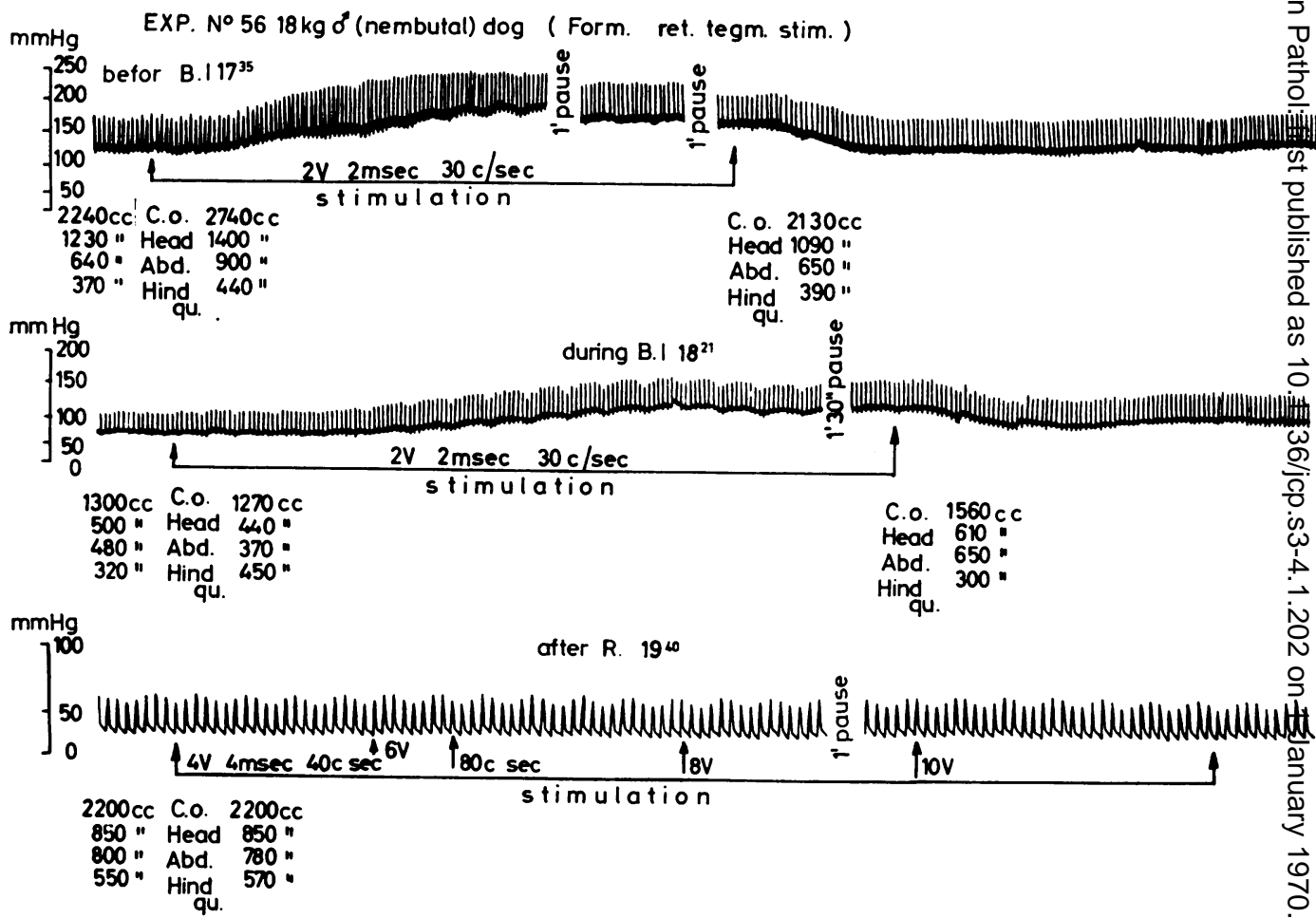

Fig. 10 The effect of stimulation of the reticular formation of a dog under nembutal anaesthesia on the bloo $\Phi$ pressure before, during, and after haemorrhage. The figures below the tracings give the total cardiac output ( $\mathrm{ml} / \mathrm{min})$ and the volumes going to the head and forelimbs, the splanchnic region, and the hindquarters (see tex).
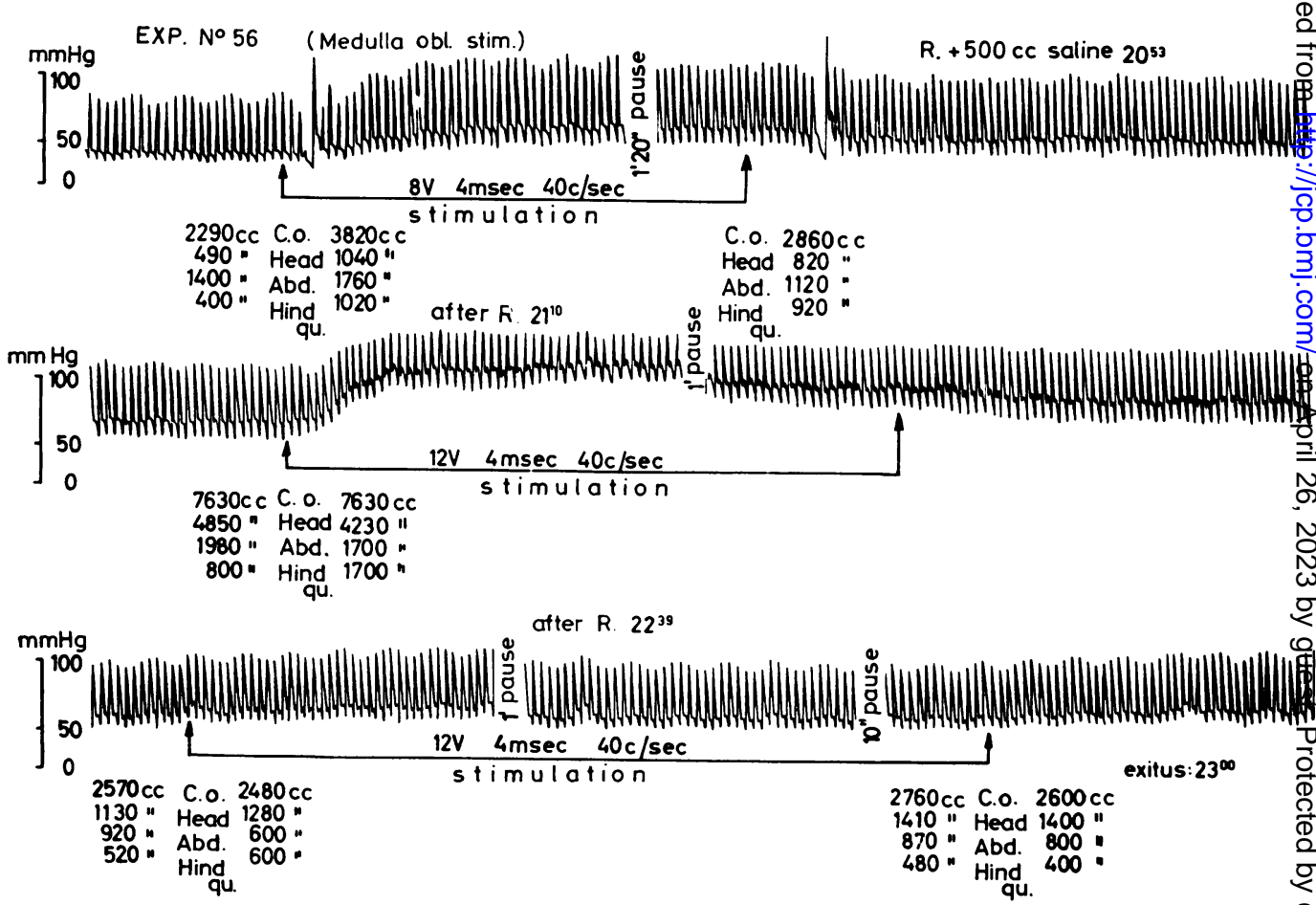

Fig. 11 The effect of stimulation of the medulla oblongata of a dog under chloralose anaesthesia on the bloo pressure during and after haemorrhage. The figures below the tracings give the total cardiac output ( $\mathrm{ml} / \mathrm{min}$ ), and the volumes going to the head and forelimbs, the splanchnic region, and the hindquarters (see tex 


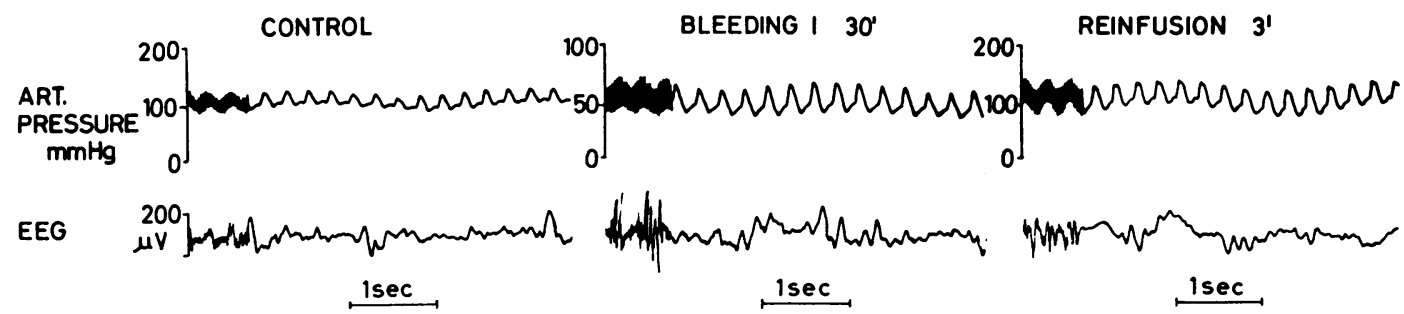

EVOKED

RESPONSE

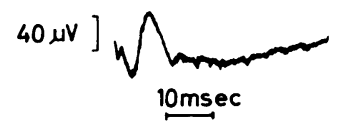

60' AFTER REINFUSION
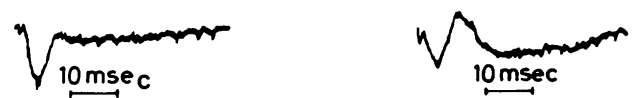

BLEEDING \| $30^{\prime}$

REINFUSION $60^{\circ}$

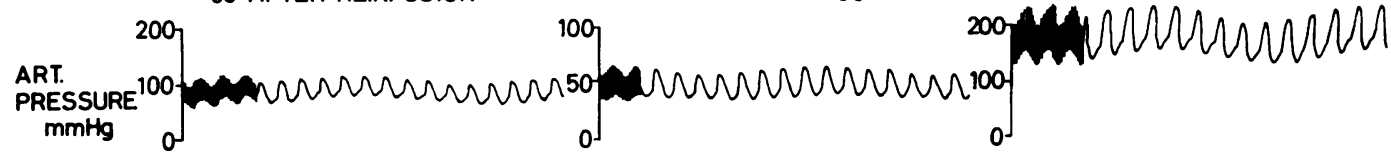

EEG
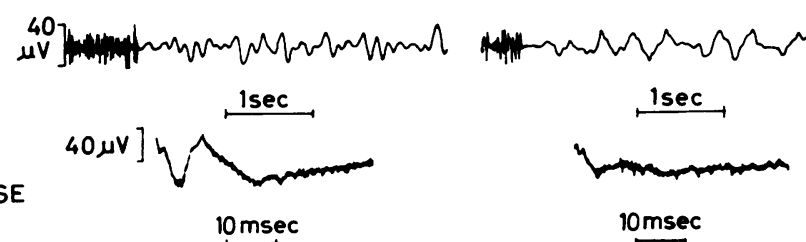

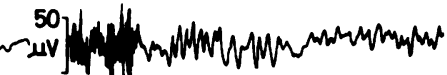

EVOKED

RESPONSE

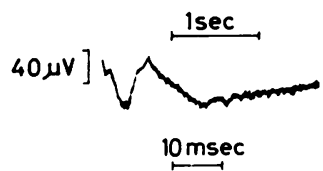

Fig. 12 The effect of haemorrhage on the evoked response in the ventromedial nucleus of the hypothalamus following stimulation of the fornix in a dog under chloralose anaesthesia.

for $30 \mathrm{~min}$ led to complete disappearance of the evoked response. The electrocortical activity, as seen in the right lower record of Fig. 12, was still normal. These results would suggest that evoked responses in the hypothalamus are impaired before the spontaneous cortical activity, and that the hypothalamus is extremely sensitive to bleeding.

\section{Conclusions}

In summary, we can conclude that the central nervous functions are seriously affected in standardized haemorrhagic shock.

The impairment of the central nervous system is not equal in all regions. The hypothalamic and perhaps the frontal cortex are specially sensitive.

Blood flow autoregulation seems less well developed in the hypothalamus, which is perhaps more vulnerable than other regions.

Cerebral, cortical, and the hypothalamic $\mathrm{O}_{2}$ utilization is raised in shock. This, together with the fall in blood flow, increases the degree of local hypoxia. In addition to the loss of circulatory control shown in these experiments the hypothalamic impairment can involve other regulatory mechanisms such as those for temperature regulation and neurohormonal secretion. The results are of interest in relation to the changes in thermoregulation after trauma described by Dr Stoner in his paper (pp. 47-55).

The protective action of phenoxybenzamine in haemorrhagic shock may be due to the metabolic as well as the pharmacological effects of the drug.

\section{References}

Anrep, G. V., Ayadi, M.S., and Talaat, M. (1936). A method for determination of carbon dioxide applicable to blood and tissues. J. Physiol. (Lond), 86, 153-161.

Arshavskaya, E. J. (1950). On the mechanism of origin of expzrimental shock in the presence of nociceptive irritation in different age pəriods. (Russian.) Fiziol. $Z h$ (Mosk.), 36, 333-341.

Aukland, K., Bower, B. F., and Berliner, R. W. (1964). Measurement of local blood flow with hydrogen gas. Circulat. Res., 14, 166-187.

Baldy-Moulinier, M., and Ingvar, D. H. (1968). EEG frequency content related to regional blood flow of cerebral cortex in cat. Exp. Brain Res., 5, 55-60.

Baubkus, H., and Kirchheim, H. (1966). Säure-basen Veränderungen im hämorrhagischen Schock. (Abstr.) Acto physiol. Acad. Sci. hung., 29, 342.

Betz, E., Braasch, D., and Hensel, H. (1961). Die Wirk ung von 2,6-bis-(diaethanolamino)-4,8-dipiperidino-pyrimido $(5,4$ d)-pyrimidin auf die Durchblutung von Myocard, Gehirn, Niere, Leber, Haut und Muskulatur. Arzneimittel-Forsch., 11, 333-336.

Betz, E., and Hensel, H. (1961). Lokale Registrierung der Gehirn durchblutung an wachen, frei beweglichen Tieren. Naturwissenschaften, 48, 527-528. 
Crile, G. W. (1899). An Experimental Research into Surgical Shock. Lippincott, Philadelphia.

Darby, T. D., and Watts, D. T. (1964). Acidosis and blood epinephrine levels in hemorrhagic hypotension. Amer. $J$. Physiol., 206, 1281-1284.

Engelking, R., and Willig, F. (1958). Ưber eine Methode zur Konstanthaltung des Blutdruckes im Tierexperiment. Pflügers Arch. ges. Physiol., 267, 306-312.

Erdélyi, A., and Kovách, A. G. B. (1961). Quoted by Kovách, A. G. B. Importance of nervous and metabolic changes in the development of irreversibility in experimental shock. Fed. Proc., 20, Suppl. 9, 122-137 (on p. 125).

Fonyó, A., Kovách, A. G. B., and Kovách, E. (1957). Functional state and cerebral, acid-soluble phosphorus fractions in traumatic shock of rats. (Hungarian.) Kisérl. Orvostud., 9, 206-211.

Fonyó, A., Kovách, A. G. B. Maklári, E., Leszkovszky, G., and Meszáros, J. (1958). The effect of potassium ions and glutamate on the incorporation of $\mathrm{P}^{23}$ into nucleotides and phosphocreatine in brain slices. Acta physiol. Acad. Sci. hung., 14, 305-307.

Fronék, A., and Ganz, W. (1960). Measurement of flow in single blood vessels including cardiac output by local thermodilution. Circulat. Res., 8, 175-182.

Guthrie, C. C. (1917). Experimental shock. J. Amer. med. Ass., 69, 1394-1398.

Hensel, H., Ruef, J., and Golenhofen, K. (1959). Fortlaufende Registrierung der Muskeldurchblutung am Menschen mit einer Calorimetersonde. Pflügers Arch. ges. Physiol., 259, 267-280.

Jourdan, F., Collet A., and Masbernard, A. (1950). Les réactions artérielles cérébrales du cours du choc traumatique. C.R. Soc. Biol. (Paris), 144, 1507-1509.

Kety, S. S. (1960). Theory of blood-tissue exchange and its application to measurement of blood flow. Meth. Med. Res., 8, 223-227.

King, B. D., Sokoloff, L., and Wechsler, R. L. (1952). The effects of $l$-epinephrine and $l$-norepinephrine upon cerebral circulation and metabolism in man. J. clin. Invest., 31, 273-279.

Koltay, E., Kovách, A. G. B., and Kovách, E. (1970). Effect of ethyl-diphenyl propenylamine and phenoxybenzamine on respiration of isolated rat liver mitochondria. Abstracts, 34th Annual Conference of the Hungarian Physiological Society, Debrecen 1968, edited by K. Lissak, p. 166. Akadémia Kiaó, Budapest.

Kovách, A. G. B. (1954). Kisérleti Orvostudomány Vizsgáló Môdszerei, vol. I. Akadémiai Kiadó, Budapest.

Kovách, A. G. B., Bagdy, D., Balázs, R., Antoni, F., Gergely, J., Menyhárt, J., Irányi, M., and Kovách, E. (1952). Traumatic shock and adenosine triphosphate. Acta physiol. Acad. Sci. hung., 3, 331-344.

Kovách, A. G. B., Dóra, E., and Nyáry, I. Unpublished.

Kovách, A. G. B., Fedina, L., Mitsányi, A., Naszlady, A., and Biró, Z. (1962). Neurophysiological and circulatory changes in hemorrhagic shock. In Proceedings of the 22nd International Congress of Physiological Sciences, Leyden, 1962, vol. 2 (Excerpta Med. Int. Congr. Ser., 48) p. 678.

Kovách, A. G. B., and Fonyó, A. (1960). Metabolic responses to injury in cerebral tissue. In The Biochemical Response to Injury, edited by H. B. Stoner and C. J. Threlfall, pp. 129160. Oxford, Blackwell.

Kovách, A. G. B., and Fonyó, A. (1965). Incorporation of ${ }^{32} \mathrm{P}$ into the rat's brain during traumatic shock. Acta physiol. Acad. Sci. hung., 27, 27-31.

Kovách, A. G. B., Fonyó, A., and Halmágyi, M. (1957). Acetylcholine content of the brain in traumatic shock. Acta physiol. Acad. Sci. hung., 13, 1-4.

Kovách, A. G. B., Fonyó, A., and Kováh, E. (1958). Creatinine phosphate resynthesis after electric stimulation of the brain of rats in shock. Acta physiol. Acad. Sci. hung., 14, 309-310.

Kovách, A. G. B., Fonyó, A., and Kovách, E. (1959a). Cerebral phosphate metabolism in traumatic shock. Acta physiol. Acad. Sci. hung., 16, 157-164.

Kovách, A. G. B., Fonyó, A., Vittay, T., and Pogátsa, G. (1957). Oxygen and glucose consumption and hexokinase activity in vitro of brain tissue of rats in traumatic shock. Acta physiol. Acad. Sci. hung., 11, 173-180.

Kovách, A. G. B., Kellner, M., and Maklári, E. (1965a). Káliumtartalom traumás shockos patkányok vérsavójában es szöveteiben. Kisérl. Orvostud., 17, 277-281.

Kovách, A. G. B., Koltay, E., and Kovách, E. (1969). Effect of phenoxybenzamine on mitochondrial respiration. Fourth International Congress on Pharmacology, Basle, p. 140.
Kovách, A. G. B., Menyhárt, J., Erdélyi, A., Molnár, G., Msss, S., Kovách, E., and Bodolay-Várga, A. (1961). The 吾le of the sympatho-adrenal system in ischaemic shock. physiol. Acad. Sci. hung., 19, 199-208.

Kovách, A. G. B., Menyhárt, J., Erdélyi, A., Molnár, G., $\underset{\text { Zñ }}{\not 2}$ Kovách, E. (1957c). The effect of dibenamine givep at different stages of ischaemic shock on survival time, in dogs, and on the oedema of their ligated limbs. 季ta physiol. Acad. Sci. hung., 13, 5-13.

Kovách, A. G. B., and Mitsányi, A. (1964). Die Wirkung Qon 4,4'- diäthylaminoäthoxy Hexöstrol auf den allgemeơen Kreislauf und die Durchblutung des Myocards. WF med. Wschr., 114, 401-405.

Kovách, A. G. B., Mitsányi, A., and Stekiel, W. (1965b). L Real blood flow and oxygen tension of brain tissue in haemorrhagic shock. (Abstr.) Acta physiol. Acad. Sci. hung. $\left.\mathrm{x}^{2}\right\}^{26}$, Suppl. 35-36.

Kovách, A. G. B., Roheim, P. S., Irányi, M., Cserháti., $\overrightarrow{\mathbb{E}}$., Gosztonyí, G., and Kovách, E. (1959b). Circulation and metabolism in the head of the dog in ischaemic shock. Acta physiol. Acad. Sci. hung., 15, 217-229.

Kovách, A. G. B., Roheim, P. S., Irányi, M., Kiss, S., and Antal, J. (1958d). Effect of the isolated perfusion of the heafon the development of ischaemic and haemorrhagic shork. Acta physiol. Acad. Sci. hung., 14, 231-238.

Kovách, A. G. B., Róheim, P. S., Irányi, M., and Kováchł́tE. (1958e). Renal function in haemorrhagic shock, with the head perfused with normal blood. Acta physiol. Anad. Sci. hung., 14, 247-254.

Kovách, A. G. B., Rosell, S., Sándor, P., Koltay, E., Tomka, Ał., and Kovách, E. (1970). Blood flow oxygen consump Hon and free fatty acid release in subcutaneous adipose tissue during hemorrhagic shock in control and phenoxybepzamine-treated dogs. Circulat. Res. In press.

Lee, J. F., Tindall, G. T., Greenfield, J. C., Jr., and Odom, G? (1966). Cerebral blood flow in the monkey. J. Neurosugeg., 24, 719-726.

McShan, W. H., Potter, V. R., Goldman, A., Shipley, E. G., and Meyer, R. K. (1945). Biological energy transformations during shock as shown by blood chemistry. Amer JJ. Physiol., 145, 93-106.

Maklári, E., and Kovách, A. G. B. (1966). Carbon dioxide content of brain tissue in control and phenoxybenzaminepretreated experimental hemorrhagic shock. (Abstr.) Afta physiol. Acad. Sci., hung., 29, 414.

Maklári, E., and Kovách, A. G. B. (1968). Carbon dioxide conß̣nt of brain tissue and acid-base balance in hemorrh shock after pretreatment with dibenzyline. Acta Acad. Sci. hung., 25, 13-22.

Maklári, E., Kovách, A. G. B., and Nyáry, I. (1970). Carbुํำ dioxide content of brain tissue after infusion of differont buffer solutions. Acta physiol. Acad. Sci. hung. In press

Menyhárt, J., Kovách, A. G. B., Kiss, S., Erdélyi, A., and Kov E. (1954). Die Wirkung von Dibenamin im ischämischen Schock. Acta physiol. Acad. Sci. hung., 5, Suppl., 32.

Mylon, E., and Winternitz, M. C. (1945). Factors concerned f $_{\text {th }}$ the induction of tourniquet shock. Amer. J. Physiol., b4, 494-504.

Overman, R. R., and Wang, S. C. (1947). The contributory $\underset{\text { Tote }}{3}$ of the afferent nervous factor in experimental shogk: sublethal hemorrhage and sciatic nerve stimulation. Amer. J. Physiol.. 148, 289-295.

Popov, L. I. (1959). Shok i krovopotjerya. Tr. Voenno-med. $\mathbb{S}_{d}$. Lenina Akad. S.M. Kirova, 102, 108-144.

Root, W. S., Allison, J. B., Cole, W. H., Holmes, J. H., Walcelt, W. W., and Gregersen, M. I. (1947). Disturbances in the chemistry and in the acid-base balance of the blood of dogs in hemorrhagic and traumatic shock. Amer ${ }_{0}^{J}$. Physiol., 149, 52-63.

Rosell, S. (1966). Release of free fatty acids from subcutanedits adipose tissue in dogs following sympathetic nqo stimulation. Acta physiol. scand., 67, 343-351.

Slome, D., and O'Shaughnessy, L. (1938). The nervous factoలin traumatic shock. Brit. J. Surg. 25, 900-909.

Stoner, H. B., and Threlfall, C. J. (1954). The effect of nucleofide and ischaemic shock on the level of energy-rich phosphes in the tissues. Biochem. J., 58, 115-122.

Swingle, W. W., Remington, J. W., Kleinberg, W., Drill, v. and Eversole, W. J. (1942). An experimental study of the tourniquet as a method for inducing circulatory failurein the dog. Amer. J. Physiol., 138, 156-165.

Van Liere, E. J., and Stickney, J. C. (1963). Effect of hypoxiaßn the nervous system. In Hypoxia, pp. 276-349. Univerfty of Chicago Press, Chicago.

Wiggers, C. J. (1950). Physiology of Shock. Commonwealth Fu P.d, New York. 